\title{
Gardner's choice
}

\section{Walter Gratzer}

The Sacred Beetle and Other Great Essays in Science.

Edited by Martin Gardner.

Prometheus, 700 East Amherst St, Buffalo, NY: 1984. Pp.427. \$22.95.

To be published in Britain later this year by Oxford University Press.

A PART of the enjoyment that an anthology affords is to stimulate the reader's prejudices, especially as to what has been omitted. My first reaction to Martin Gardner's collection of essays was regret that modesty should have deterred him from including some of the most entertaining of modern science writing, to be found in his own books, such as In the Name of Science and Science, Good, Bad and Bogus. Other notable omissions are J.B.S. Haldane, whose entire oeuvre I should have been tempted to retain, and Medawar, as well as the English natural historians, such as Richard Jefferies and Gilbert White. There are, however, many pleasurable surprises in this highly individual selection - a somewhat enlarged hardback version of a paperback published in 1957 (which is no doubt why the late Samuel Goudsmit, whose dates are correctly given as 1902-1978, is stated to be the current chairman of the Physics Department at Brookhaven).

Gardner has disinterred some late nineteenth century romantics, such as John Burroughs, throbbing with Victorian fervour and sincerity, and (to me at least) a rather glutinous read. There are some choice examples of the thinking of Freud and of Havelock Ellis, which could be said to stretch the definition of science. Attend:

... fair hair is more beautiful because it harmonises better with the soft outlines of woman, ... the hair of the armpits, also, Stratz considers, should be light. On the other hand, the pubic hair should be dark in order to emphasize the breadth of the pelvis and the obliquity of the angle between the mons veneris and the thighs.

And so on for pages. (If one suspected Havelock Ellis of the possession of a sense of humour one might well wonder whether he had not invented the unlikely Stratz perhaps the original inspiration for $\mathrm{Dr}$ Strabismus of Utrecht, whom God preserve.) Then we are assailed by Maeterlinck on the bee, apostrophizing the reader in remorselessly purple prose. (How incomparably better Miriam Rothschild.) Fabre, on the other hand, is irresistible, his slightly dotty enchantment with the habits of the dung beetle a constant delight.

Julian Huxley's dissertation on the courtship of birds seems oddly dated, with its patina of anthropomorphism. The crested grebe, he avers, though constrained by the shackles of monogamy, flirts, when frustrated, with passing ladies; his consort, who until then has remained indifferent to his advances, thereupon attacks and drives off her rival, and only after this is there a loving reconciliation. "How human", Huxley muses, "again we see to what a pitch of complexity the bird's emotional life is tuned". Well perhaps, though to me it only recalls the cartoon that shows the zoo gorilla bearing away a shrieking blonde; her husband, observing with composure, suggests: "Why don't you tell him you've got a headache?".

There are some well-chosen contributions by Darwin and T.H. Huxley, whose majestic cadences retain their power to hold the reader in thrall. Stephen Jay Gould makes his appearance in the new edition (in the company of Asimov, Sagan and Lewis Thomas), with a beautifully wrought essay on the amorality of nature and the contortions of the Victorian moralists in the face of such Grand Guignol as the behaviour of the ichneumon fly, which injects its eggs into a caterpillar, so that the larvae, when they hatch, devour the still living but paralysed host from within. The best that a leading entomologist and divine of the day could manage, to justify God's ways to man, was to praise the maternal regard of the wasp in undertaking its hazardous operation. (His predicament has been encapsulated in the words of one of our latter-day gurus: the leopard will lie down with the kid, but the kid won't get much sleep.)

Among the more surprising appearances in The Sacred Beetle are those of G.K. Chesterton, Robert Louis Stevenson, John dos Passos and a science editor of Time magazine, Jonathan Norton Leonard.
There is also A.N. Whitehead, seeking to reconcile science and religion, and vexing Galileo's ghost with an ingenious rehabilitation of pre-Galilean astronomy by recourse to relativity. Ortega y Gasset inveighs against science, which he evidently feared would destroy the values of European civilization by spawning a new breed of insufferable and dangerous "learned ignoramuses", too narrow in education and vision to recognize the limitations of their competence. This is a sustained piece of polemical virtuosity, and one cannot help but wonder how Ortega, a pillar of the Spanish Republic, got along with his Prime Minister and fellow professor, Juan Negrín, a physiologist, who chose to organize a scientific meeting in Madrid at the height of the Civil War with the enemy already at the very gates. Did he even perhaps have Negrín in mind?

Among other pleasures that Gardner puts in our way in this odd but engaging book are Goudsmit's account of what he found when he entered Germany with the US Army in 1945 to investigate how science had fared under Hitler; a dazzling philippic on determinism by Eddington; two essays by Bertrand Russell, pellucid in substance as in style; and H.G. Wells, as compelling now as then in a chapter from one of the scientific romances. Here he is in a passage that Gardner has quarried from an almost forgotten novel, Meanwhile:

The disease of cancer will be banished from life by calm, unhurrying, persistent men and woman $\ldots$ and the motive that will conquer cancer will not be pity nor horror; it will be curiosity to know how and why. 'And the desire for service', said Lord Tamar. "As the justification for that curiosity', said Mr Sempack 'but not as the motive. Pity never made a good doctor, love never made a good poet. Desire for service never made a discovery'.

Well said, H.G.!

Walter Gratzer is in the Medical Research Council's Cell Biophysics Unit, King's College, University of London.

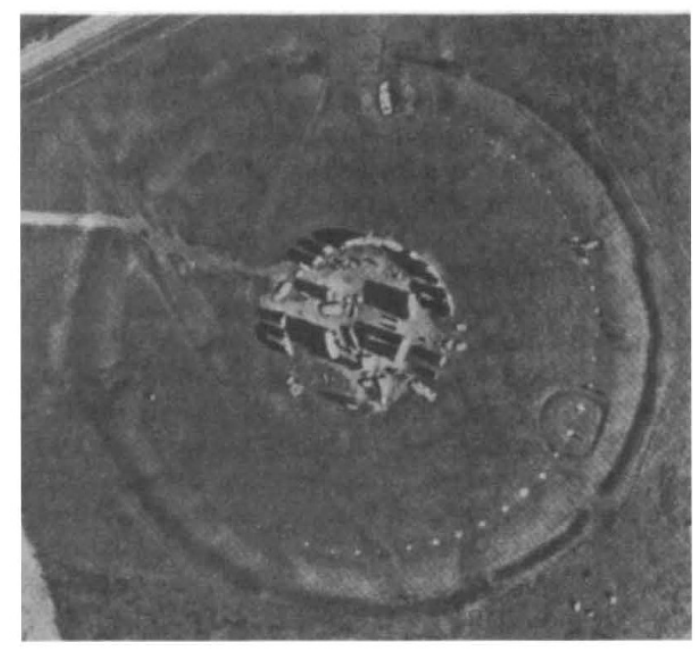

Stonehenge from the air, showing the outer ditch and bank as well as the standing stones themselves. The photograph is reproduced from Prehistoric Europe by Timothy Champion, Clive Gamble, Stephen Shennan and Alasdair Whittle. Publisher is Academic Press. The book will be reviewed in Nature's textbook supplement, which will appear in the issue of 7 March. 